\title{
Selective Adsorption of CPTMS-SBA-15 towards Zinc and Cadmium for Liquid Waste Remediation
}

\author{
Donanta Dhaneswara ${ }^{1 *}$, Dewantoro Adhy Putranto ${ }^{1}$, Muhammad Bachtiar ${ }^{1}$, Jaka Fajar \\ Fatriansyah $^{1}$ \\ ${ }^{1}$ Departement of Metallurgical and Materials Engineering, Faculy of Engineering, Universitas \\ Indonesia, Kampus Baru UI 16424 Depok, Jawa Barat, Indonesia
}

\begin{abstract}
Mesoporous silica SBA-15 has been synthesized using Tetraorthosilicate as precursor and Pluronic 123 triblock copolymers as template through the sol gel method. The surface of SBA-15 was modified using functionalization agent CPTMS (3-chloropropyl(trimethoxy)silane). SBA-15 was found to have surface area of $831.996 \mathrm{~m}^{2} / \mathrm{g}$ higher than CPTMS-SBA-15 which has surface area at $711.061 \mathrm{~m} 2 / \mathrm{g}$. Laboratory water sampels of $\mathrm{Zn}$ and $\mathrm{Cd}$ were adsorbed by CPTMS-SBA- 15 and SBA15. The comparison of SBA-15 and CPTMS-SBA-15 indicated that CPTMS-SBA-15 has lower surface and pore size. CPTMS-SBA-15 also has lower effectiveness in adsorption than SBA-15. The comparison between $\mathrm{Zn}$ and $\mathrm{Cd}$ percentage removal has been studied in this paper. XRD was used for identify the materials. FTIR was used to study the organic group of both SBA-15. AAS was used for determine the adsorption capability of SBA- 15 .
\end{abstract}

\section{Introduction}

The industrialization process in Indonesia has side effects of environmental contamination such as soil, water and air pollution. Soil pollution by heavy metal such as zinc, lead, copper and others in industrial areas in Jabodetabek (Jakarta, Bogor, Depok, Tangerang and Bekasi) is very high and has a bad impact for people around the industrial areas[1]. The population of Indonesia concentrated in the industrial and sorrounding areas reaching $6 \%$ of Indonesia's population[2], the impact of heavy metal pollution will be enormous. Hazardous heavy metals includes Zinc (Zn), Mercury (Hg), Cadium (Cd), Chromium (Cr) and others. This waste is discharged and this liquid waste usually flows into rivers around industrial areas for example in Jakarta. Along with the development of the city, it will continously supply the heavy waste into the river. And it is proven that the rivers located in Jakarta have been contaminated by various types of heavy metals and it is dangerous for local people[3].

Development in nanotechnology has produced many advanced materials and it has benefits more than conventional materials. These materials have an extraordinary properties

\footnotetext{
* Corresponding author: farhan.delayori@ui.ac.id
} 
compared to conventional materials. One of these materials is the mesoporous silica SBA15 which has a surface area up to $400 \mathrm{~m}^{2} / \mathrm{g}[4]$ which has wide application such as in separation[5,6], optics[7,8], catalyst $[9,10]$ and as nano template materials[11,12]. SBA-15 is a mesoporous silica material which has a uniform hexagonal pore structure. The pore diameter of SBA-15 is between 5 to $15 \mathrm{~nm}[13]$ and the thickness of structural walls is 3.1 to $6.4 \mathrm{~nm}$. Based on the SBA-15 large surface area, SBA-15 material is applicable as an adsorbent.

The ability of SBA-15 for heavy metal as an adsorbent has been demonstrated by Mihaela el.Al(1998) on some havy metals such as Zinc (Zn) and Cobalt (Co). SBA-15 that is used for this study is synthesized using Zhang et.Al[14] method. This methodemploys amphiphilic triblock co-polymers. Donanta D. Et. Al [15] has been successfully synthesized SBA-15 using Pluronic 123 with a simpler method. In this study, the SBA-15 will be used as an adsorbent material for Zinc and Cadmium heavy metal. It is expected that our materials can reduce the concentration of Zinc and Cadmium in waste water.

Here, SBA-15 as a mesoporous material is functionalized. Functionalization is purposed to enhance adsorption capability of SBA-15 towards heavy metals. Several agentswhich have been used for functionalization are CPTMS[16], THPP [16] and APTES[17]. CPTMS has Chlor atom which accommodatessingle electron pair to metallic cation and it interacts strongly each other. Hence, the present study is aimed to synthesize CPMTS-SBA-15 using the process that has been done by Asgari et.al[16]. The first part of this work discusses the synthesis and characterization of CPTMS-SBA-15 and the last part discusses investigation of the adsorption ability of CPMTS-SBA-15 inzinc(II) and $\mathrm{Cd}(\mathrm{II})$ ions removal from aqueous solution.

\section{Experimental}

\subsection{Material}

Tetraethyorthosilicate (TEOS) which is used as silica precursor was purchased from Merck and Pluronic $\mathrm{P} 123^{\circledR}$ as template was purchased from Sigma Aldrich. 3chloropropyltrimethoxysilane (CPTMS) and toluene were purchased from Sigma Aldrich. Those materials were used without any purification.

\subsection{Synthesis SBA-15 and CPTMS-SBA-15}

Sol-gel process was used to synthesized SBA-15 using TEOS as a precursor and surfactant Pluronic $123^{\circledR}$ as a template. There are 4 require basic solution to synthesis of SBA- 15 . Solution I consists of TEOS with $5 \mathrm{ml}$ ethanol.Solution II was needed to create acidic condition which consists of $10 \mathrm{ml}$ of $\mathrm{HCl}(2 \mathrm{M})$ with $5 \mathrm{ml}$ ethanol.Solution III consists 50 $\mathrm{ml} \mathrm{H}_{2} \mathrm{O}$ with $10 \mathrm{ml}$ ethanol and solution IV consists surfactant Pluronic $123^{\circledR}$ with $25 \mathrm{ml}$ of ethanol and $10 \mathrm{ml}$ of $\mathrm{HCl}(2 \mathrm{M})$. First, solution II and III are mixed.Then, the mixture was further mixed again with solution I by stirring for 30 minutes. The resulting mixture of those three solutions was refluxed at $50^{\circ}-60^{\circ} \mathrm{C}$ for 2 hours and then was added drop wisely with solution IV. Then, the solution was dried at $100^{\circ} \mathrm{C}$ for 1 hours and then calcined at $400^{\circ} \mathrm{C}$ for 5 hours. Mesoporous SBA-15 material was obtained and ready to use.

Mesoporous SBA-15 was functionalized with (3-chloropropyltrimethoxysilane)/CPTMS. The functionalization process begins by dissolving 0.4 grams of SBA-15 into $25 \mathrm{ml}$ toluene. Then, CPTMS was added dropwise by $2.8 \mathrm{ml}$ into the toluene solution. This solution is refluxed at $110^{\circ} \mathrm{C}$ for 24 hours. The precipitate of the reflux is filtered and washed using toluene and ethanol. Then, it was dried using an oven at $100^{\circ} \mathrm{C}$ for 24 hours. The result of this process is called CPTMS-SBA-15. 


\subsection{Characterization}

Both of SBA-15 and CPTMS-SBA-15 were done with various characterizations to obtain their characteristics. Transmission electron microscopy/TEM (Tecnai G2 spirit Win) was used to identify the mesostructure. A PerkinElmer Fourier transform infrared (FTIR) was performed to get the information of functional groups. Small-angle x-ray diffraction (SA$\mathrm{XRD}$ ) with $\mathrm{Cu} \mathrm{K} \alpha$ radiation were used to measure crystal structure and orientation of pure SBA-15 and CPTMS-SBA-15. Nitrogen adsorption-desorption analysis was performed by quantachrome adsorption-desorption equipment at $77 \mathrm{~K}$ to get the information of mesopores volume, pore size and specific surface area. Determination of zinc and cadmium concentration was conducted using atomic absorption spectrophotometry (Shimadzu).

\section{4 $\mathrm{Zn}$ and $\mathrm{Cd}$ ion adsorption test}

To determine the optimum values of SBA-15 as adsorbant of $\mathrm{Zn}$, following procedure is conducted.Initial concentration of $100 \mathrm{mg} / \mathrm{L} \mathrm{Zn}$ was obtained by dissolving $\mathrm{Zn}\left(\mathrm{NO}_{3}\right)_{2}$ into distilled water with the variations of adsorbant $100 \mathrm{mg} / \mathrm{L}, 500 \mathrm{mg} / \mathrm{L}, 1 \mathrm{~g} / \mathrm{L}$ and $1,5 \mathrm{~g} / \mathrm{L}$. Solution was stirred for 100 minutes at $300 \mathrm{rpm}$.Furthermore, thisobtained optimum value of adsorbantis used in adsorption experimentof varying $\mathrm{Zn}$ concentration of $20 \mathrm{mg} / \mathrm{L}, 60$ $\mathrm{mg} / \mathrm{L}, 100 \mathrm{mg} / \mathrm{L}$ and $140 \mathrm{mg} / \mathrm{L}$. Then, the solution was stirred for 100 minutes at $300 \mathrm{rpm}$. Similar procedure was conducted for Cd adsorption. In this case, $40 \mathrm{mg} / \mathrm{L}, 80 \mathrm{mg} / \mathrm{L}$ and $120 \mathrm{mg} / \mathrm{L}$ of adsorbant concentration were used. In Cd adsorption experiment, $50 \mathrm{mg} / \mathrm{L}$, $100 \mathrm{mg} / \mathrm{L}, 250 \mathrm{mg} / \mathrm{L}, 400 \mathrm{mg} / \mathrm{L}$ and $500 \mathrm{mg} / \mathrm{L}$ of concentration were used. The solution was stirred for 15 mins in room temperature at $100 \mathrm{rpm}$.

\section{Result and discussion}

\subsection{Characterization}

Silica mesoporous SBA-15 material has been successfully synthesized with precursor TEOS and surfactant Pluronik P123 ${ }^{\circledR}$. CPTMS has been sucessfully used for functionalization agent for SBA-15. Chlorine as main functional group of CPTMS as shown in the figure1 may increase the adsorption capacity of SBA-15 of heavy metal by trapping cations via ionic interaction. The possibly structure of CPTMS-SBA-15 shown in figure 2 withattachedchlor in the end of SBA-15 bond.

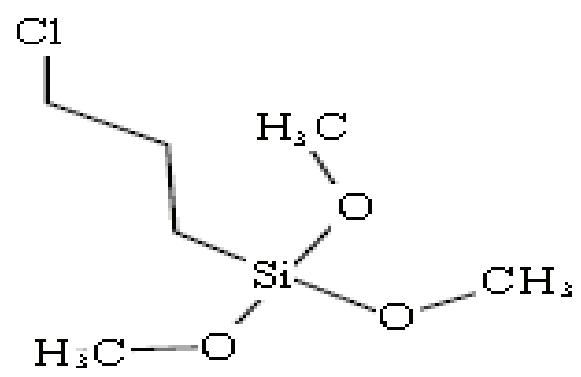

Fig.1. Structure of CPTMS 


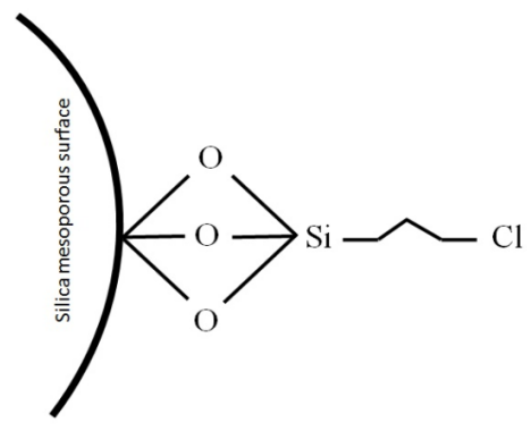

Fig. 2. The Possible Structure of CPTMS-SBA-15

TEM image of mesoporous SBA-15 and CPTMS-SBA-15 can be seen in the figure 3 (a) and 3 (b). The nano sized pores were observed which shows parallel cylindrical pores of 2D hexagonal unit cell as a trademark of SBA-15[18]. Figure 3 (b) shows that the surface of CPTMS-SBA-15 looks brighter which is caused by the modification by methyl and chlor. CPTMS as functionalization agent is found to be dispersed around the SBA-15 as seen as white particles shown in TEM result.

The Small Angle X-Ray Diffraction was used to determine SBA-15 and CPTMS-SBA15 crystallinity. The samples peak point of SAXRD of $2 \Theta$ at near 0.3683 and another peak point near 0.6547 . Based on figure 4 , both of samples show relatively close peak on (100) that clarifies surface wallsand peaks of (110) and (200)that clarify pore structure. These three peaks show the samples has 2D hexagonal pore structure [19]. CPTMS-SBA-15 has lower peaks than SBA-15.This is caused by alteration of ordered mesostructure SBA-15 as a result of functionalization of $\mathrm{Cl}$ in the surface of mesoporous silica[16].
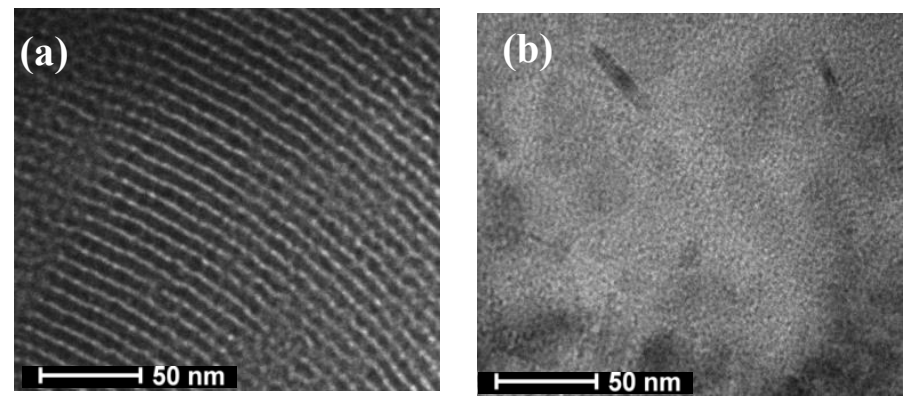

Fig. 3. TEM images for (a) SBA-15 and (b) CPTMS-SBA-15

Fig. 5 shows about the $\mathrm{N}_{2}$ adsorption-desorption isotherms result of both SBA-15. Both samples show same curves that can be classified as a irreversible adsorption-desorption type IV. Type IV shows possibility of interconected networks, cillydrically structure of pores and capillary condensation phenomenon [15]. Hysteresis loop occurs at range 0.6-0.8 elative pressure for SBA-15 and 0.6-0.7 for CPTMS-SBA-15. The hysteresis form is classified as category $\mathrm{H} 1$ which is associated with a porous materials containing cylindrical pore channels [15]. From the curves, it shows relatively unchanged form which means that the functionalization did not change the surface/pore structures. 


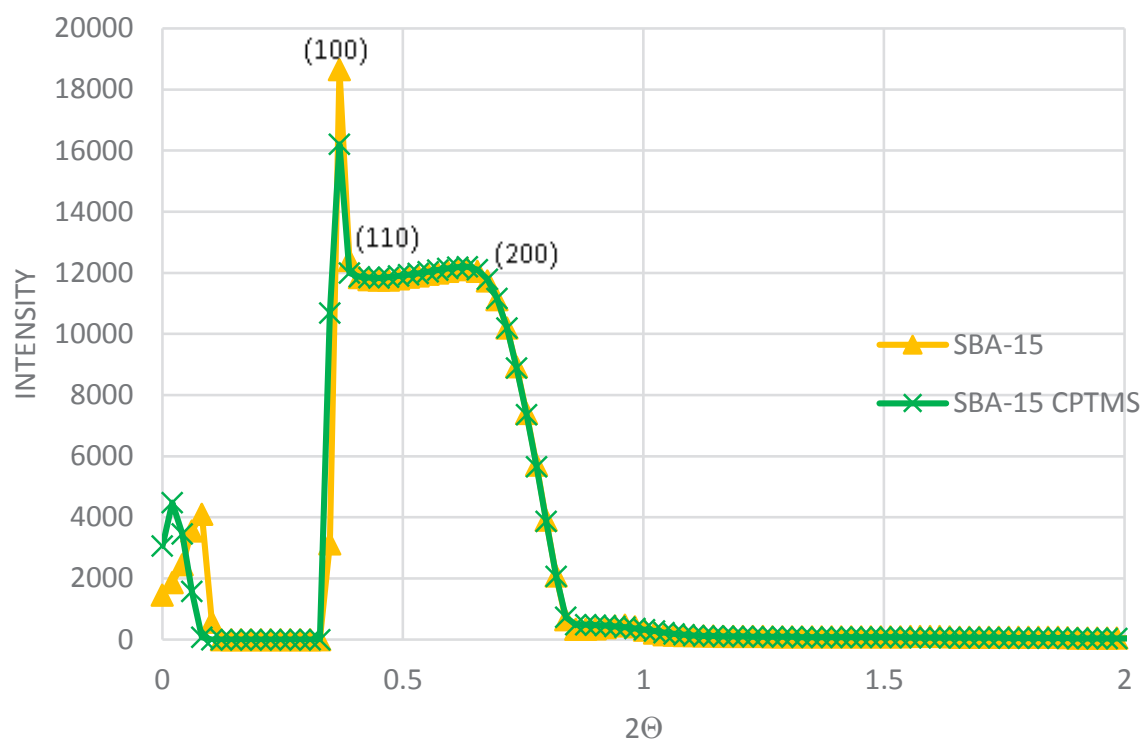

Fig. 4. SAXRD SBA-15 and CPTMS-SBA-15

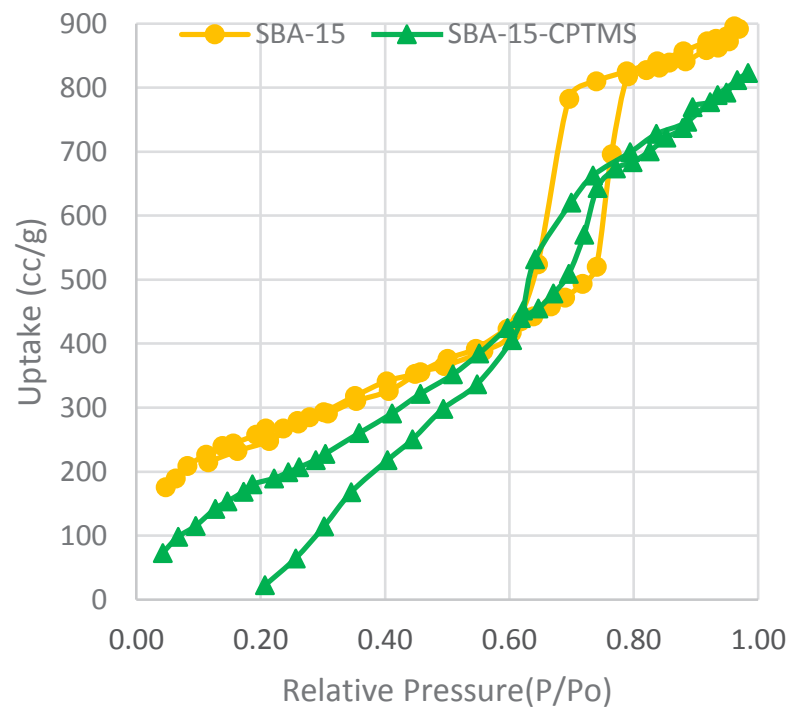

Fig. 5. The $\mathrm{N}_{2}$ adsorption-desorption curves of SBA-15 and CTPMS-SBA-15 


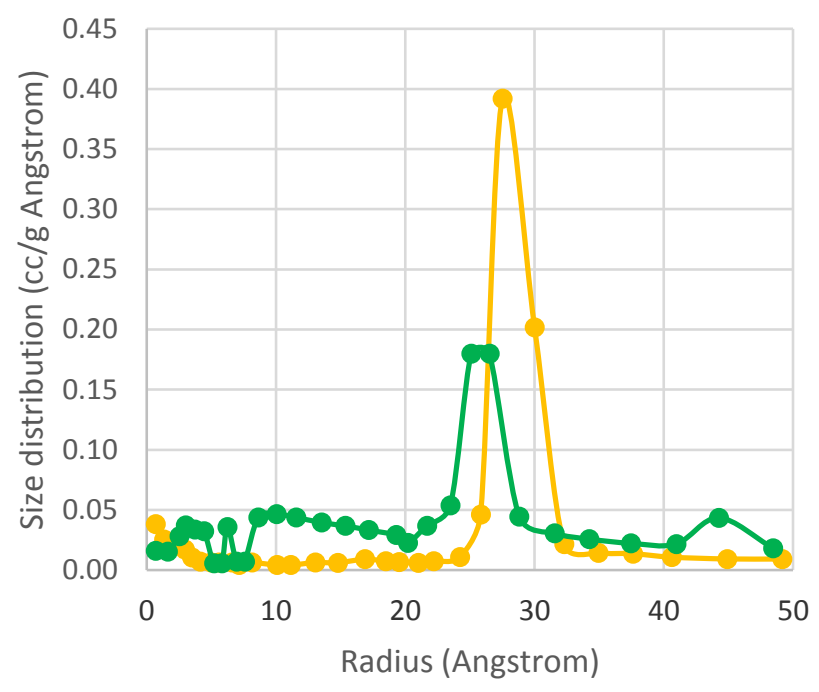

Fig. 6. The size distribution of SBA-15 and CPTMS-SBA-15

Figure 6 shows that the maximum pore diameter with high size distribution curve of SBA-15 is around 29.203 $\AA$. CPTMS-SBA-15 has lower pore size with relatively same distribution curve. Functionalized SBA-15 has less ordered structure than pure SBA-15 because the peak of distribution curve is lower. However, it is safe to assume that there is no significant change of pore diameter and structure due to the functionalization.

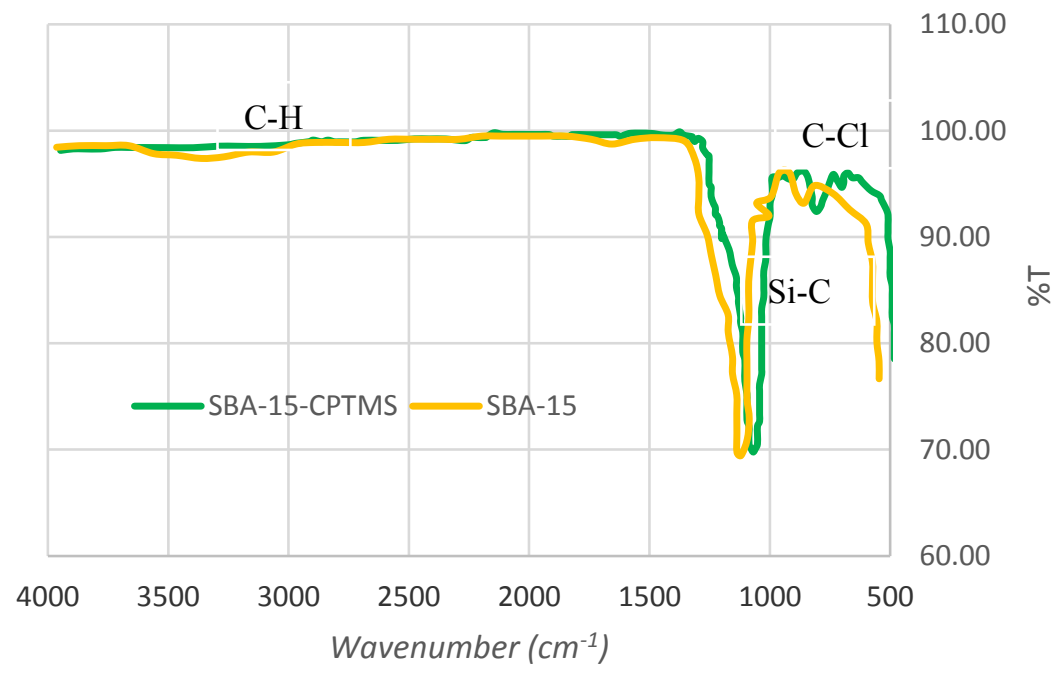

Fig. 7. SBA-15 and CPTMS-SBA-15 FTIR Results

Figure 7 shown that there is symmetric-assymetric stretching of C-H bonds at 2950$2850 \mathrm{~cm}^{-1}$. There is also a vibration of Si-C bond at $722 \mathrm{~cm}^{-1}$. Chlor as a part of functionalization agent has been indentified at $500 \mathrm{~cm}^{-1}$ as a $\mathrm{C}-\mathrm{Cl}$ bond. This means that CPTMS is successfully functionalizedonto SBA-15.

The result of BET measurement can be seen in table 1 that shows the diameter of CPTMS-SBA-15 is smaller than SBA-15. Smaller diameter of pore in CPTMS-SBA-15 yields lower specific surface area and pore volume. The lower size of pore, volume and 
surface area of CPTMS-SBA-15 infers that the Chlor can be located not only in the surface but also inside the pores. This result is relevant to $\mathrm{N}_{2}$ adsorption-desorption result in figure 5 which demonstrates that the gas uptake of CPTMS-SBA-15 is lower than SBA-15. The bond between SBA-15 and Chlor also can be identified by observing the decrease of pore diameter of CPTMS-SBA-15.

Table 1. BET result of characterisics of adsorbant

\begin{tabular}{||lccc||}
\hline & $\begin{array}{c}\text { Pore Diameter } \\
(\AA)\end{array}$ & $\begin{array}{c}\text { Pore Volume } \\
(\mathrm{cc} / \mathrm{g})\end{array}$ & $\begin{array}{c}\text { Specific Surface } \\
\text { Area }\left(\mathrm{m}^{2} / \mathrm{g}\right)\end{array}$ \\
\hline \hline SBA-15 & $\mathbf{2 9 . 2 0 3}$ & $\mathbf{2 6 5 . 1 6 1}$ & $\mathbf{8 3 1 . 9 9 6}$ \\
CPTMS-SBA-15 & $\mathbf{2 8 . 5 2 1}$ & $\mathbf{1 9 9 . 6 4 9}$ & $\mathbf{7 1 1 . 0 6 1}$ \\
\hline
\end{tabular}

\subsection{Adsorbant optimum value}

Figure 8 shows about the result of adsorption by varying adsorbant concentration for $\mathrm{Zn}$ removal and figure 9 for Cd removal. $0.5 \mathrm{~g} / \mathrm{L}$ of SBA-15 can remove $66.7 \% \mathrm{Zn}$ from solution. The highest removal was found for $1.5 \mathrm{~g} / \mathrm{L}$ of adsorbant which removes $77 \%$ of $\mathrm{Zn}$. It can be determined that the optimum concentration of SBA-15 as an adsorbant for $\mathrm{Zn}$ removal is $1 \mathrm{~g} / \mathrm{L}$ due to the small disparity between the removal of $1 \mathrm{~g} / \mathrm{L}$ and $1.5 \mathrm{~g} / \mathrm{L}$. This concentration of $1 \mathrm{~g} / \mathrm{L} \mathrm{SBA}-15$ will be used in the next adsorption test of $\mathrm{Zn}$ heavy metal.

Figure 9 shows the removal percentage with variousSBA-15 and CPTMS-SBA-15 concentration for Cadmium adsorption. The removal percentage of SBA-15 is lower than CPTMS-SBA-15. It shows that the increase of adsorbant concentration increasesthe removal percentage.

The highest removal was found for the concentration of $120 \mathrm{mg} / \mathrm{L}$ which has percentage of removalof $63.98 \%$. This concentration of adsorbant will be used for SBA-15 and CPTMS-SBA-15 in the next adsorption test of Cadmium.

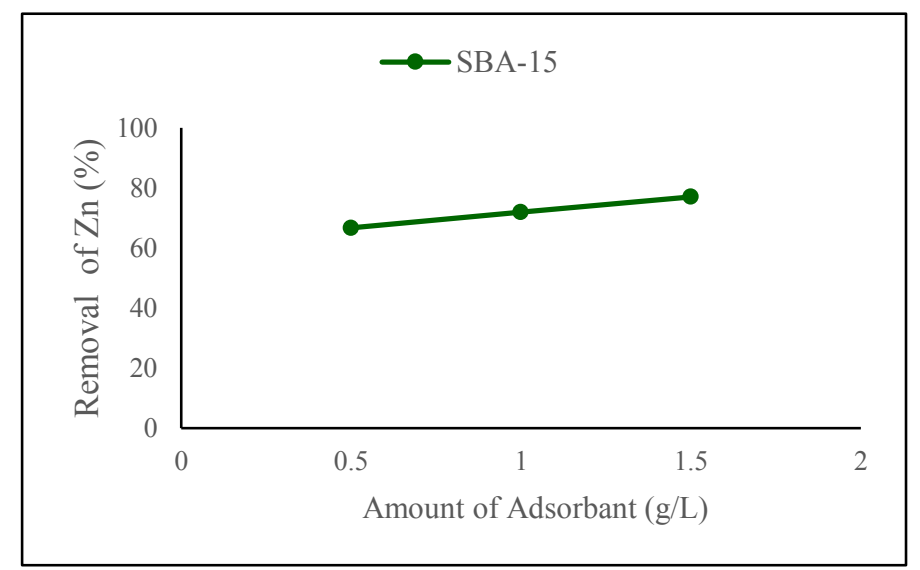

Fig. 8. Effect of amount of adsorbant on Zinc removal 


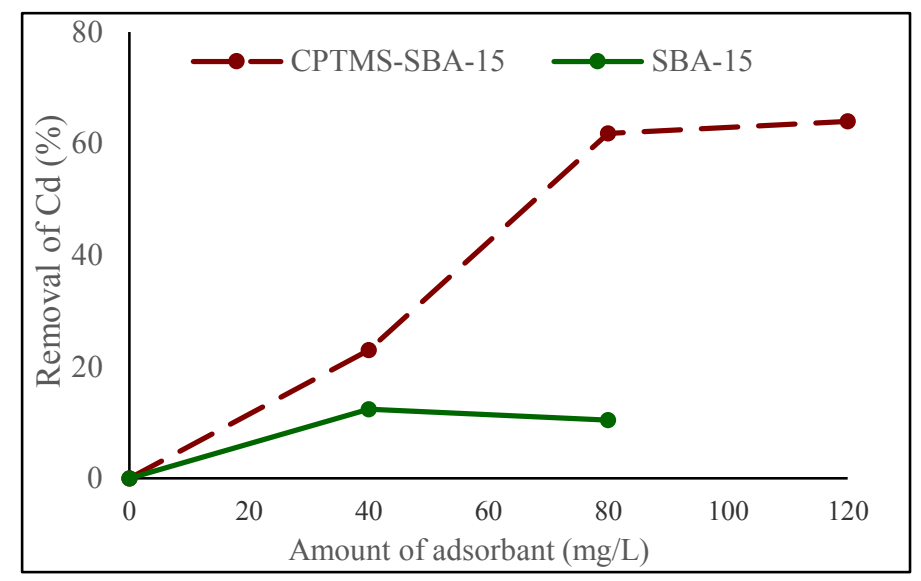

Fig. 9. Effect of amount of adsorbant on cadmium removal

\subsection{Adsorption of $\mathrm{Zn}$ and Cadmium}

The result of adsorption of Zinc can be seen in figure 10. It shows that as the concentration of SBA-15 was increased, the removal capacity becomes lower. According to figure 10, in the case of SBA-15, the percentage of removal at $60 \mathrm{mg} / \mathrm{L}$ of $\mathrm{Zn}$ is $44.67 \%$ and the highest concentration of $\mathrm{Zn}$ is at $140 \mathrm{mg} / \mathrm{L}$ with the percentage of removal $7.8 \%$. In the other hand, for CPTMS-SBA-15, the result of percentage of removal at $60 \mathrm{mg} / \mathrm{L}$ for $\mathrm{Zn}$ is $11 \%$ and at $140 \mathrm{mg} / \mathrm{L}$ of $\mathrm{Zn}$ is $6.5 \%$. It can observed that the removal efficiency of CPTMS-SBA- 15 is lower than SBA-15.

The removal efficiency of $\mathrm{Cd}^{2+}$ were carried out by $\mathrm{Cd}^{2+}$ ion adsorption test. Theinvestigation of $\mathrm{Cd}$ removal has been observed by measuring the initial and final concentration of $\mathrm{Cd}$ ion. Based on the results of $\mathrm{Cd}$ adsorption test, the $\mathrm{Cd}$ initial concentration at $50 \mathrm{ppm}$ has the highest removal percentage $60 \%$. The increasing of $\mathrm{Cd}$ initial concentration will be followed by the decreasing of adsorption removal percentage. It's due to the increasing of heavy metal concentration is not proportional to the increase of amount of SBA-15.

The lower efficiency in $\mathrm{Zn}$ adsorption system may be due to the larger differences of electronegativity between Chlor and $\mathrm{Zn}$ in comparison with the Chlor and $\mathrm{Cd}$ system. The surface of SBA-15 was modified by CPTMS and causing chlor attach in the end of bond of SBA-15. 


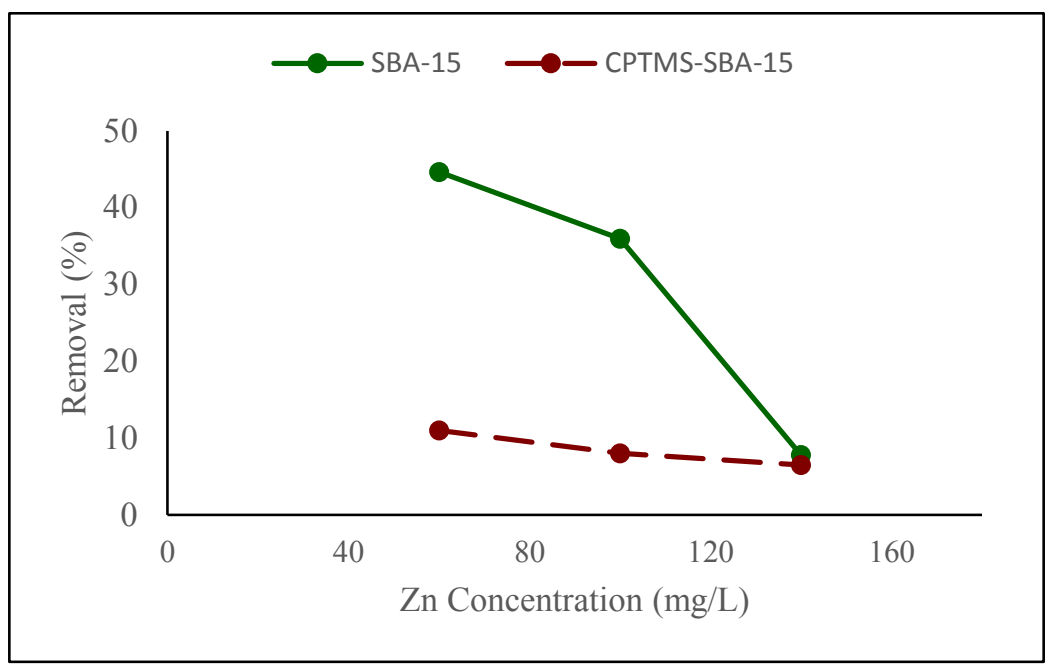

Fig. 10. The comparison of initial concentration on $\mathrm{Zn}$ removal

Table 2. The comparison of initial concentration on $\mathrm{Cd}$ removal

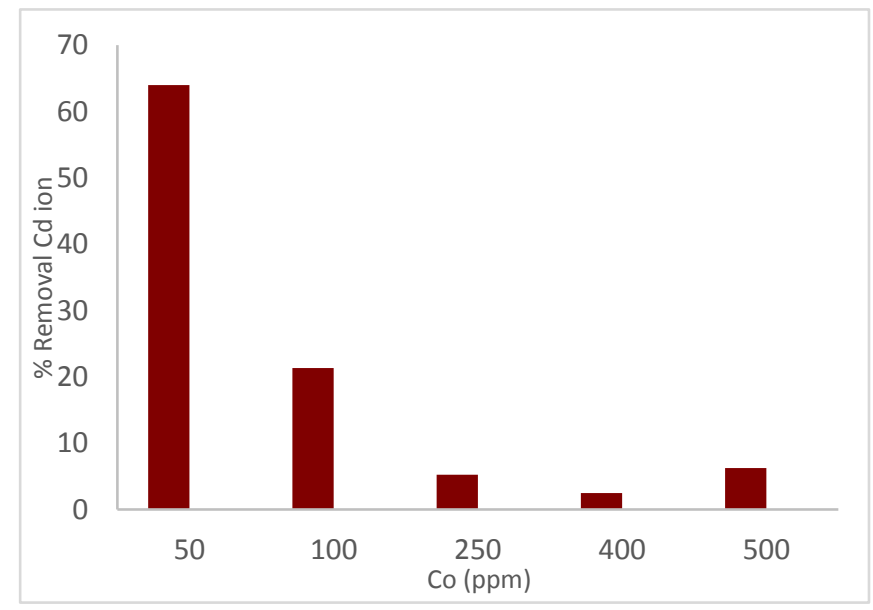

\section{Conclusion}

SBA-15 has been successfully synthesized with TEOS and Pluronik P123 ${ }^{\circledR}$ then functionalized with CPTMS. SBA-15 pores is hexagonal structure. The functionalization reduced specific area, diameter pore and volume. This is occure because inside the pores and on the surface has a chlor ion. Zinc as heavy metal samples has lower efficiency of adsorption with CPTMS-SBA-15 than $\mathrm{Cd}$. It may be due to the differences of electronegativity between $\mathrm{Zn}$ and Chlor is higher in comparison with the $\mathrm{Cd}$ and Chlor system. It caused $\mathrm{Zn}$ was merely attached to the surface of CPTMS-SBA-15 while on the other hand $\mathrm{Cd}$ is able to be adsorb properly throughout the pore of adsorbant. Due to its smaller pore size and also surface area, it was strengthen the fact that CPTMS-SBA-15 has lower adsorbtion properties of $\mathrm{Zn}$. 


\section{References}

1. PALAR H, "Pencernaan dan Toksikologi Logam Berat”, PT Rineka Cipta Jakarta, (1994)

2. Central Bureau of Statistics,"Population Projection by Province", 2010-2035"., (2015).

3. Yudo, Satmoko, “KondisiPencemaranLogam Berat di Perairan Sungai DKI Jakarta”. Pusat Teknologi Lingkungan-BPPT, 2, 1, (2006).

4. J. P. Thielmann, F. Girgsdies, R. Schlogl and C. Hess, "Pore Structure and Surface Area of Silica SBA-15: Influance of Washing and Scale-up," Beilstein Journal of Nanotechnology, 2,13, 110-118, (2011).

5. Hoang, V. T.; Huang, Q.; Eic, M.; Do, T. O.; Kaliaguine, S. Langmuir, 21, 2051-2057, (2005).

6. Han, Y. J.; Stucky, G. D.; Butler, A. Journal. Am. Chemical. Society, 121, 9897-9898, (1991).

7. Scott, B. J.; Wirnsberger, G.; Stucky, G. D. Chemical Material, 13, 3140-3150, (2001).

8. Yang, P.; Wirnsberger, G.; Huang, H. C.; Cordero, S. R.; McGehee, M. D.; Scott, B.; Deng, T.; Whitesides, G. M.; Chmelka, B. F.; Buratto, S. K.; Stucky, G. D. Science, 287, 465-467, (2000).

9. Hess, C. "Nanostructured Vanadium Oxide Model Catalyst for Selective Oxidation Reaction", ChemPhysChem,10, 2,(2009).

10. Cavalleri, M.; Hermann, K.; Knop-Gericke, A.; Hävecker, M.; Herbert, R.; Hess, C.; Oestereich, A.; Döbler, J.; Schlögl, R. J. Catal., 262, 215-223, (2009).

11. Ryoo, R.; Ko, C. H.; Kruk, M.; Antochshuk, V.; Jaroniec, M. J. Physical. Chemical. B, (2000).

12. Lu, A. Schüth, F. Advance. Material., 18, 1793-1805, (2006).

13. Zhao, D. Y.; Feng, J. L.; Huo, Q. S.; Melosh, N.; Fredrickson, G. H.; Chmelka, B. F.; Stucky, G. D. Science, 279, 548-552, (1998).

14.Zhao, D., Huo, Q., Feng, J., Chmelka, B.F., Stucky, G.D, "Nonionic Triblock and Star Diblock Copolymer and Oligomeric Surfactant Syntheses of Highly Ordered, Hydrothermally Stable, Mesoporous Silica Structures”, Journal Am. Chemical Society. 120, 6024-6036, (1998).

15. D. Dhaneswara, Studi Pengaruh Peningkatan Konsentrasi Surfaktan Pluronik P123 terhadap Karakteristik Pori Material SBA-15, Depok: Universitas Indonesia, (2006).

16. Guozhong Cao, "Nanostructures and Nanomaterials : Synthesis, Properties and Application”, Imperial College Press, UK, 5, (2003).

17. Guozhong Cao, "Nanostructures and Nanomaterials : Synthesis, Properties and Application”, Imperial College Press, UK, 238, (2003).

18. Zhao, D. "Triblock Copolymer Syntheses of Mesoporous Silica with Periodic 50 to 300 Angstrom Pores. Science”, 279(5350), 548-552, (1998).

19. Su, F., Zeng, J., Bao, X., Yu, Y., Lee, J. Y., \& Zhao, X. S., "Preparation and characterization of highly ordered graphitic mesoporous carbon as a Pt catalyst support for direct methanol fuel cells", Chemistry of materials, 17(15), 3960-3967, (2005). 